\title{
Risk factors for infection with Aeromonas salmonicida subsp. salmonicida in Norwegian freshwater hatcheries
}

\author{
J. Jarp ${ }^{1}$, K. Tangen ${ }^{2}$, F. V. Willumsen ${ }^{2}$, H. O. Djupvik ${ }^{3}$, A. M. Tveit ${ }^{3}$ \\ ${ }^{1}$ Central Veterinary Laboratory, POB 8156 Dep., N-0033 Oslo 1, Norway \\ ${ }^{2}$ OCEANOR a.s., Pirsenteret, N-7005 Trondheim, Norway \\ ${ }^{3}$ Fusa and Kvam forsøksring, N-5640 Eikelandsosen, Norway
}

\begin{abstract}
In 1991, a matched case-control study was performed in Norwegian freshwater hatcheries on risk factors for infection with Aeromonas salmonicida subsp. salmonicida, the causative agent of furunculosis. The study was based on replies to a questionnaire mailed to smolt producers, and included 30 infected and 66 non-infected hatcheries, matched by county. The odds ratios for infection with $A$. salmonicida subsp. salmonicida in hatcheries associated with certain management and environmental factors were analyzed using a conditional logistic regression analysis. The study revealed that the main risk factors for infection with $A$. salmonicida subsp. salmonicida in freshwater hatcheries were: (1) migration of anadromous fish into the freshwater supply of the hatchery, (2) sharing of personnel with other fish farms, and (3) a high concentration of fish farms infected with A. salmonicida subsp. salmonicida near the hatchery. Results indicate that the high prevalence of furunculosis in Norwegian seawater farms has great impact on the risk of infection with $A$. salmonicida subsp. salmonicida in hatcheries, and also that the bacterium may be transmitted between fish farms by humans.
\end{abstract}

KEY WORDS: Atlantic salmon - Epidemiology - Furunculosis - Hatcheries

\section{INTRODUCTION}

Furunculosis was diagnosed for the first time in farmed Atlantic salmon Salmo salar L. in Norway in 1985. The disease is now considered to be endemic in the major fish breeding areas along the coast. However, in recent years, the incidence of furunculosis has remained low in freshwater hatcheries, while being high in seawater farms. Consequently, the disease is regarded mainly as a seawater disease in the farmed fish population.

Fish diseases, as with diseases in general, have a multifactorial etiology, their occurrence being associated with the environment of the fish, internal host factors, and the infectious agent. The presence of an infectious agent in a host will not necessarily lead to overt disease. Some fish may carry Aeromonas salmonicida subsp. salmonicida without developing furunculosis, but may well transmit the infection to other fish.
Therefore, freshwater hatcheries in which A. salmonicida subsp. salmonicida has been isolated are not allowed to market their smolts. Such sites must be depopulated and subjected to sanitary procedures, as specified by the Norwegian Fish Diseases Act, if they are again to become smolt suppliers. As the economic losses involved are considerable, it is of the utmost importance that hatcheries prevent the introduction of the infection into their fish populations.

At present, the knowledge of factors predisposing to or causing diseases in farmed fish is relatively sparse compared to that for diseases in other intensively reared animals. The Norwegian farmed fish population represents an excellent target population for epidemiological studies, providing as it does the large sample sizes that are necessary if such studies are to give conclusive results. Epidemiological methods are useful tools for the analysis of associations between potential risk factors and the presence of specific infec- 
tions or diseases with a known or unknown etiology. Epidemiological studies may help to identify risk factors for fish diseases, and quantify their effect on disease, and thereby contribute to more efficient disease control in fish populations.

In case-control studies, the distribution of several exposure factors is compared between a sample of diseased and a sample of healthy units. The results of a case-control study will give the estimated odds of being a case when a given exposure factor is present compared to that when the factor is absent. The aim of the present study was to investigate the significance of various management and environmental factors as potential risk factors for infection with Aeromonas salmonicida subsp. salmonicida of Atlantic salmon in Norwegian hatcheries in a matched case-control study.

\section{MATERIALS AND METHODS}

Design. The study was designed as a matched casecontrol study (Schlesselman 1982) with the freshwater hatchery as the unit of concern and the county as the matching factor. The matching strategy was one of frequency matching performed by the random selection of controls within each county in a proportion of 2 controls per case.

Farms. A case hatchery was defined as one licensed by the Norwegian Directory of Fisheries for the production of Atlantic salmon smolts as of 1 October 1988. In the case hatcheries Aeromonas salmonicida subsp. salmonicida had been isolated from Atlantic salmon

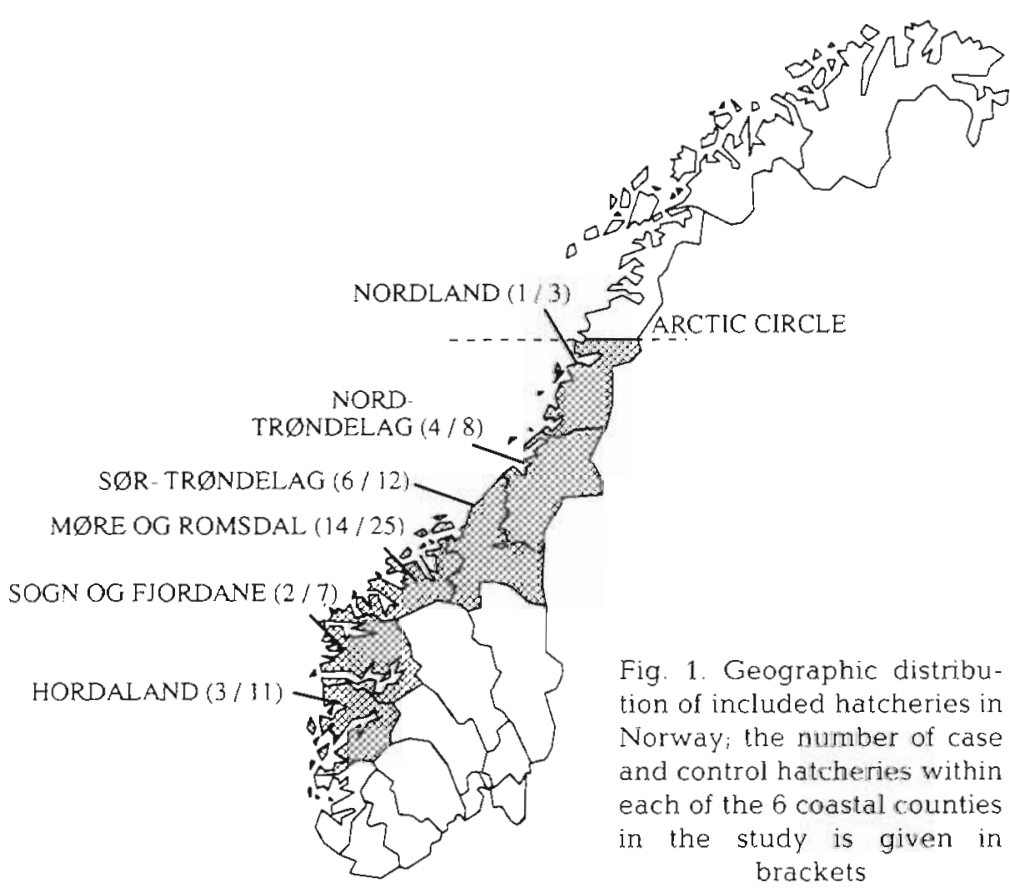

as verified by one of the Norwegian State Veterinary Laboratories during the period 1 October 1988 to 1 January 1991. A control hatchery was defined as a hatchery licensed to produce Atlantic salmon smolts according to the same criteria as the case hatchery, but in which, over the same time period, A. salmonicida subsp. salmonicida had not been isolated from the fish stocks. Hatcheries organized by local angling clubs for restocking purposes, as well as hatcheries suspected but not confirmed to be infected, were excluded from the study. All hatcheries in which $A$. salmonicida subsp. salmonicida had been isolated, as registered by the Norwegian Department of Veterinary Services in the period from 1 October 1988 to 1 January 1991, fulfilled the criteria and were considered potential cases for the study. These potential cases were geographically distributed in 6 coastal counties, stretching from Hordaland in the south to Nordland in the north. Hatcheries in all 6 counties were included in the study (Fig, 1).

Questionnaire. The material in the study was based on the answers to a questionnaire mailed to the selected breeders at the beginning of 1991. The questionnaire was resubmitted to the primary non-responders after 2 wk. In addition, the breeders were contacted by telephone and requested to give answers, either by filling in the questionnaire or by giving the information directly by phone. Initially the questionnaire was sent to all the 44 case hatcheries available and to 88 control hatcheries, but due to the lack of response the questionnaire was sent to more hatcheries, the final overall total being 152. Two hatcheries did not fulfil the criteria for inclusion in the study, because they produced rainbow trout

The questionnaire consisted of 10 questions, con-cerning: (1) the use of fresh water supplies allowing the possible entry of anadromous fish, (2) the purchase of fry from other sites, (3) the sharing of equipment for fish vaccination with other fish farms, (4) the sharing of working staff with other fish farms, (5) the number of fish farms within a $10 \mathrm{~km}$ radius from the hatchery, (6) the number of fish farms in which Aeromonas salmonicida subsp. salmonicida had been isolated within a $10 \mathrm{~km}$ radius from hatchery, (7) the distance between the hatchery and the sea, (8) the number of rivers with a natural stock of anadromous salmon within a $25 \mathrm{~km}$ radius of the hatchery, (9) the number of years that the hatchery had been in production up to 1991, and (10) the licensed maximum annual production quota of the hatchery (Table 1). Fish slaughter facilities and official units for disposal of fish 
Table 1. Distribution of potential risk factors in the 30 case hatcheries and 66 control hatcheries included in the study and results of univariate conditional logistic regression analysis

\begin{tabular}{|c|c|c|c|c|c|}
\hline Risk factor & $\begin{array}{l}\text { Level of } \\
\text { categorization } \\
\text { in analysis }\end{array}$ & $\begin{array}{l}\text { No. in } \\
\text { cases } \\
(N=30)\end{array}$ & $\begin{array}{l}\text { No. in } \\
\text { controls } \\
(N=66)\end{array}$ & $\begin{array}{c}\text { Odds ratio of } \\
\text { infection (95\% } \\
\text { confidence interval) }\end{array}$ & $\begin{array}{l}\mathrm{p} \text {-value of } \\
\text { univariate } \\
\text { model }^{\mathrm{a}}\end{array}$ \\
\hline $\begin{array}{l}\text { Access of anadromous fish to water } \\
\text { supplies }\end{array}$ & $\begin{array}{l}\text { Yes } \\
\text { No }\end{array}$ & $\begin{array}{l}14 \\
16\end{array}$ & $\begin{array}{r}7 \\
59\end{array}$ & $\begin{array}{l}9.3(2.8-30.7) \\
1\end{array}$ & $<0.001$ \\
\hline Purchase fry & $\begin{array}{l}\text { Yes } \\
\text { No }\end{array}$ & $\begin{array}{r}9 \\
21\end{array}$ & $\begin{array}{l}25 \\
41\end{array}$ & $\begin{array}{l}0.8(0.3-2.0) \\
1\end{array}$ & 0.591 \\
\hline $\begin{array}{l}\text { Share vaccination equipment with } \\
\text { other fish farms }\end{array}$ & $\begin{array}{l}\text { Yes } \\
\text { No }\end{array}$ & $\begin{array}{l}11 \\
19\end{array}$ & $\begin{array}{l}13 \\
53\end{array}$ & $\begin{array}{l}2.3(0.8-6.5) \\
1\end{array}$ & 0.121 \\
\hline $\begin{array}{l}\text { Share working staff with other } \\
\text { fish farms }\end{array}$ & $\begin{array}{l}\text { Yes } \\
\text { No }\end{array}$ & $\begin{array}{l}16 \\
14\end{array}$ & $\begin{array}{l}17 \\
49\end{array}$ & $\begin{array}{l}3.1(1.3-7.6) \\
1\end{array}$ & 0.011 \\
\hline Density of fish farms in neighbourhood & $\begin{array}{l}>3 \text { farms } \\
\leq 3 \text { farms }\end{array}$ & $\begin{array}{l}14 \\
16\end{array}$ & $\begin{array}{l}19 \\
47\end{array}$ & $\begin{array}{l}2.1(0.9-5.2) \\
1\end{array}$ & 0.098 \\
\hline $\begin{array}{l}\text { Density of fish farms infected with } \\
\text { furunculosis in neighbourhood }\end{array}$ & $\begin{array}{l}>2 \text { farms } \\
\leq 2 \text { farms }\end{array}$ & $\begin{array}{l}14 \\
16\end{array}$ & $\begin{array}{l}12 \\
54\end{array}$ & $\begin{array}{l}3.7(1.4-9.6) \\
1\end{array}$ & 0.007 \\
\hline Distance from hatchery to sea & $\begin{array}{l}\leq 15 \mathrm{~m} \\
>15 \mathrm{~m}\end{array}$ & $\begin{array}{l}15 \\
15\end{array}$ & $\begin{array}{l}35 \\
31\end{array}$ & $\begin{array}{l}1.2(0.5-3.1) \\
1\end{array}$ & 0.661 \\
\hline Number of salmon rivers & $\begin{array}{l}\geq 1 \\
0\end{array}$ & $\begin{array}{r}27 \\
3\end{array}$ & $\begin{array}{l}41 \\
25\end{array}$ & $\begin{array}{l}4.7(1.3-16.8) \\
1\end{array}$ & 0.109 \\
\hline Age of hatchery & $\begin{array}{l}>9 \mathrm{yr} \\
\leq 9 \mathrm{yr}\end{array}$ & $\begin{array}{l}11 \\
19\end{array}$ & $\begin{array}{l}21 \\
45\end{array}$ & $\begin{array}{l}1.2(0.5-2.9) \\
1\end{array}$ & 0.681 \\
\hline Annual number of smolts produced & $\begin{array}{l}\leq 450000 \\
>450000\end{array}$ & $\begin{array}{l}17 \\
13\end{array}$ & $\begin{array}{l}28 \\
38\end{array}$ & $\begin{array}{l}1.6(0.7-3.8) \\
1\end{array}$ & 0.221 \\
\hline
\end{tabular}

waste were also included in the variables of fish farm density. The period of interest for the management questions was from 1 October 1988 to 1 January 1991.

Statistical analysis. A conditional logistic regression analysis (Hosmer \& Lemeshow 1989) was performed in EGRET (Statistics and Epidemiology Research Corporation, Seattle, USA, 1991) with the specific infection status of the hatchery as the dependent dichotomous variable, and with the county as the stratifying variable. There were no missing values for any of the independent variables. Continuous variables were categorized in the analysis (Table 1) because the increased risk of infection per unit increase in the independent variable was not constant for any of them. Different levels of categorization of the independent variables were tested in the model before the final categories were determined in the multivariate stage.

Initially, univariate conditional logistic regression analyses were performed for each independent variable. All risk factors with a significance level below 0.25 were then offered for inclusion in a multivariate conditional logistic regression analysis. Various multivariate models were tested with the likelihood ratio test in which the difference in deviance between the models was compared against the chi-square distri- bution with the appropriate degrees-of-freedom. Potential changes in the size of the regression coefficients in the different models were analyzed to assess correlation between the independent variables. Choice of the final multivariate model was decided on the basis of the likelihood ratio tests and on the significance level of the included variables. Possible interactions between all the variables included in the multivariate model were investigated. The only significant biologically plausible terms included the matching factor, but the interaction terms were excluded from the final model, because the low observation number in the material caused problems in the model conversion.

\section{RESULTS}

The study eventually involved 96 hatcheries of which 30 were cases and 66 controls, giving an average of 2.2 controls per case. The overall response rate to the questionnaire was $64.0 \%: 68.2 \%$ for cases and $60.4 \%$ for controls. The explanations for failure to respond were: no production in the hatcheries at the time of questionnaire submission (28); the license was given for combined freshwater and seawater production, and Aeromonas salmonicida subsp. salmonicida had only 
Table 2. Adjusted odds ratios ${ }^{\alpha}$ with $95 \%$ confidence limits and p-value of regression coefficients of risk factors for infection with Aeromonas salmonicida subsp. salmonicida in freshwater hatcheries ${ }^{b}$

\begin{tabular}{|c|c|c|c|}
\hline Risk factor & $\begin{array}{l}\text { Level of } \\
\text { categorization } \\
\text { in analysis }\end{array}$ & $\begin{array}{l}\text { Odds ratio with } \\
95 \% \text { confidence } \\
\text { limits }\end{array}$ & $\begin{array}{c}\text { Wald-based p-value } \\
\text { of the regression } \\
\text { coefficients }\end{array}$ \\
\hline $\begin{array}{l}\text { Access of anadromous fish to } \\
\text { water supplies }\end{array}$ & $\begin{array}{l}\text { No } \\
\text { Yes }\end{array}$ & $\begin{array}{l}1 \\
11.5(3.2-42.1)\end{array}$ & $<0.001$ \\
\hline $\begin{array}{l}\text { Density of fish farms infected } \\
\text { with furunculosis }\end{array}$ & $\begin{array}{l}\leq 2 \text { farms } \\
>2 \text { farms }\end{array}$ & $\begin{array}{l}1 \\
3.2(0.99-10.2)\end{array}$ & 0.051 \\
\hline $\begin{array}{l}\text { Share working staff with } \\
\text { other fish farms }\end{array}$ & $\begin{array}{l}\text { No } \\
\text { Yes }\end{array}$ & $\begin{array}{l}1 \\
2.8(0.95-8.2)\end{array}$ & 0.063 \\
\hline
\end{tabular}

been isolated in fish in the seawater unit (9); unknown reasons (19). Examination of the distribution of the hatcheries within the 6 counties revealed that most of the hatcheries were located in the middle of the area (Fig. 1).

Table 1 provides the descriptive statistics of the independent variables in the material and the results of a univariate conditional logistic regression analysis. The analysis revealed that the purchase of fry, the distance from the sea, and the age of the hatchery had no influence on the risk of infection with Aeromonas salmonicida subsp. salmonicida.

The results from the final multivariate model are shown in Table 2 . The specified likelihood ratio statistic (27.7) for the model was calculated by comparison with an empty model. The $p$-value $(p<0.001)$ indicates a very small probability that the coefficients of the various parameters were zero. The most significant risk factor for infection with Aeromonas salmonicida subsp. salmonicida in the hatchery was the use of water supplies in which anadromous fish could migrate. The odds for the occurrence of infection increased by 11.5 if such migration was possible, compared to those hatcheries using water supplies inaccessible to anadromous fish. The risk of infection was also associated with the location of the freshwater hatchery in relation to other furunculosis-positive sites. If the number of fish farms infected with Aeromonas salmonicida subsp. salmonicida within a radius of $10 \mathrm{~km}$ from the hatchery exceeded 2, the risk of introducing the infection increased by 3.2. The odds ratio of sharing personnel with other fish farms was 2.8 . The regression coefficient of sharing staff was reduced by approximately $15 \%$ when the concentration of infected fish farms was included in the model, showing that the 2 variables were correlated

An extension of the multivariate conditional logistic regression with other variables was not significant. An extension of the presented final multivariate model with the variable of several salmon rivers in the neighbourhood of the hatchery was the last extension considered (Likelihood ratio statistics $=2.24$, $p>0.10)$.

\section{DISCUSSION}

The results from this case-control study support the theory that the main risk factor for the introduction of Aeromonas salmonicida subsp. salmonicida into confined fish populations in fresh water is migration of infected anadromous fish into the water supply, as suggested by McCarthy (1977). Both wild and cultured fish populations may be infected with $A$. salmonicida subsp. salmonicida, and the prevalence of furunculosis in sea-reared salmonids in Norway is high. Thus, the risk of transmitting the infection to marine and anadromous fish is significant. Marine and anadromous fish are known to feed on waste pellets around net pen sea farms (Carss 1990), and $A$. salmonicida subsp. salmonicida has been isolated from several fish species caught near sea farms (Willumsen 1990). Large numbers of domestic sea-reared salmonids have escaped from net pen farms in recent years (Jahnsen 1990), and an increasing number of salmon caught in Norwegian rivers have proved to be escaped farmed fish (Lund et al. 1991). The majority of escaped salmon ascend rivers near the home farm (Gausen \& Moen 1991). If the escaping salmon are carriers of $A$. salmonicida subsp. salmonicida, the impact on feral fish or on freshwater salmon farms in the neighbourhood of the farm may be significant. Several experimental studies have confirmed that confined fish will be infected if exposed to the pathogen in contaminated water (McCarthy 1977 , Adams et al. 1987, Rose et al. 1989). Diseased and dead fish with furunculosis are considered to be important sources of A. salmonicida subsp. salmonicida (MCCarthy 1977). The bacterium has been shown to sur- 
vive and remain infective for some days outside the host both in seawater and in fresh water, although the survival capability is a subject of debate (Williamson 1929, Lund 1967, McCarthy 1977, Allen-Austin et al. 1984, Rose et al, 1990a, b). However, the role of live salmonids which may be latent carriers of the bacterium may be even more important than dead fish.

The increased risk of infection with Aeromonas salmonicida subsp. salmonicida in the hatcheries surrounded by infected fish farms indicates that a high prevalence of furunculosis in seawater farms has great impact on the risk of infection in freshwater hatcheries. In a case-control study performed in Norwegian sea farms rearing Atlantic salmon, an increased risk of infection with infectious salmon anaemia (ISA) was found to be associated with high density of infected fish farms (Vågsholm et al. 1991). The present study did not show any significant effect of the purchase of fry on the risk of infection with $A$. salmonicida subsp. salmonicida. Sharing of fish vaccination equipment between farms increased the risk of infection, but not significantly at a $10 \%$ confidence level in the univariate model. Twenty-five percent of the hatcheries included in the study shared equipment, but since vaccination of salmonids is not often carried out during the seawater phase, the equipment was usually shared between hatcheries rather than between hatcheries and sea farms. Another explanation for the non-significance of this effect might be that equipment is thoroughly washed and disinfected before use. In the present study, the potential risk of infection within the hatcheries associated with the use of undisinfected seawater in smolt tanks was not investigated. During the time period in question a ban against the addition of seawater was introduced by the Ministry of Agriculture, unless a satisfactory system for disinfection of the seawater was installed. In some hatcheries raw seawater in the smolt tanks may have been used in the early part of the time period covered by the study.

The geographic distribution of salmonid smolt hatcheries and sea cage farms in Norway is such that hatchery working staff are most likely to be shared with a salmonid sea cage farm, a high risk partner as far as infection with Aeromonas salmonicida subsp. salmonicida is concerned. It is well established in animal husbandry that human traffic may transfer infectious agents from one closed production unit to another, and humans are often considered as the main vector for importing infectious microorganisms onto animal farms (Mohammed et al. 1987. Hedger \& Mann 1989). Since staff sharing has also been shown to be significantly associated with an increased risk of ISA in seawater farms in Norway (Vaggsholm et al. 1991), fish breeders should reconsider the practice. In general, it is important that existing knowledge of epizoo- tiology is fully taken into account in the control of fish diseases

This study was performed by analyzing data from a questionnaire distributed directly to smolt producers, and the reliability and validity of the collected data are therefore difficult to evaluate. The rate of nonresponse and the use of historic data may have introduced bias into the study. A differential recall bias may have resulted in overestimation of the effect of possible migration of anadromous fish in the hatchery fresh water supply on the odds ratio for infection with Aeromonas salmonicida subsp. salmonicida, because much attention has been drawn to this question. Few epidemiological studies on fish diseases have been performed. The most common strategy for data collection has been questionnaires (Thorburn 1987. Lillehaug 1989, Vågsholm et al. 1991). Despite the fact that the quality of questionnaire studies is not always satisfactory (Vaillancourt et al. 1991), future epidemiological studies of fish diseases will nevertheless continue to be based, at least in part, on data collection by means of questionnaires, since the systematic registration of disease-related data in Norwegian fish farms, and elsewhere, is of variable quality

The classification of cases and controls in the present study was based on a verified isolation of Aeromonas salmonicida subsp. salmonicida in the fish in the period concerned. According the National Fish Disease Act purchase of smolts from hatcheries is not permitted unless the hatcheries are regularly inspected by veterinarians (at least 12 times per year). In the control farms, such veterinary control has not revealed infection with $A$. salmonicida subsp. salmonicida in examined fish samples. Therefore, misclassification of the negative hatcheries is not very likely to have happened.

Overall, the present study revealed risk factors for infection with Aeromonas salmonicida subsp. salmonicida which accorded well with factors known to be significant for the transmission of animal diseases in general. It is therefore important to take such knowledge into account when developing strategies for the structure of the fish farm industry, as well as in the daily management of fish farms.

\section{LITERATURE CITED}

Adams, A., Leschen, W., Wilson, A., Horne, M. T (1987). A. bath challenge model for furunculosis in rainbow trout, Salmo gairdneri Richardson, and Atlantic salmon, Salmo salar L. J. Fish Dis. 10: 495-504

Allen-Austin, D., Austin, B., Colwell, R. R. (1984). Survival of Aeromonas salmonicida in river water. FEMS Microbiol Lett. 21: 143-146

Carss, D. N. (1990). Concentrations of wild and escaped fishes immediately adjacent to fish farm cages. Aquaculture 90 : $29-40$ 
Gausen, D., Moen, V. (1991). Large-scale escapes of farmed salmon (Salmo salar) into Norwegian rivers threaten natural populations. Can. J. Fish. Aquat. Sci. 48: $426-428$

Hedger, R. S., Mann, J. A. (1989). Swine vesicular disease virus. In: Pensaert, M. B. (ed.) Virus infections of porcines. Elsevier Scientific Publ., Amsterdam, p. 241-250

Hosmer, D. W., Lemeshow, S. (1989). Applied logistic regression. John Wiley \& Sons, New York

Jahnsen, T. (1990). Rømt oppdrettslaks. Fiskets gang 4: 10-12 (in Norwegian)

Lillehaug, A. (1989). A survey on different procedures used for vaccinating salmonids against vibriosis in Norwegian fish-farming. Aquaculture 83: 217-226

Lund, M. (1967). A study of the biology of Aeromonas salmonicida (Lehmann and Neumann 1896) Griffin 1954. M.Sc. thesis, Univ. of Newcastle-upon-Tyne

Lund, R. A., Økland, F., Hansen, L. P. (1991). Farmed Atlantic salmon (Salmo salar) in fisheries and rivers in Norway. Aquaculture 98: 143-150

McCarthy, D. H. (1977). Some ecological aspects of the bacterial fish pathogen - Aeromonas salmonicida. In: Skinner, F. A., Shewanả, J. M. (eds.) Aquatic microbiol., Symposium of the Society for Applied Bacteriology No. 6. Academic Press, London, p. 299-324

Mohammed, H. O., Carpenter, T E., Yamamoto, R. (1987). Evaluation of factors associated with infection of commercial layers with Mycoplasma gallisepticum and $M$. Synoviae. Avian Dis. 31: 470-476

Rose, A. S., Ellis, A. E., Munro, A. L. S. (1989). The infectivity by different routes of exposure and shedding rates of

Responsible Subject Editor: T. Evelyn, Nanaimo, B.C., Canada
Aeromonas salmonicida subsp. salmonicida in Atlantic salmon, Salmo salar L., held in sea water. J. Fish Dis. 12 $573-578$

Rose, A. S., Ellis, A. E., Munro, A. L. S. (1990a). Evidence against dormancy in the bacterial fish pathogen Aeromonas salmonicida subsp. salmonicida. FEMS Microbiol. Lett. 68: 105-108

Rose, A. S., Ellis, A. E., Munro, A. L. S. (1990b). The survival of Aeromonas salmonicida subsp. salmonicida in sea water. J. Fish Dis. 13: 205-214

Schlesselman, J. J. (1982). Case-control studies. Oxford University Press, New York

Thorburn, M. A. (1987). Factors influencing seasonal vibriosis mortality rates in Swedish pen-reared rainbow trout. Aquaculture 67: 79-85

Vågsholm, I, Tangen, K., Willumsen, F, V., Djupvik, H. O., Tveit, A. M. (1991). Risikofaktorer for ILA - en 'case-control' studie. Nor. Fiskeoppdrett 6: 36-37 and 7: 28-29 (in Norwegian

Vaillancourt, J.-P., Martineau, G., Morrow, M., Marsh, W., Robinson, A. (1991). Construction of questionnaires and their use in veterinary medicine. In: Thrusfield, M. V. (ed.) Proceedings from the Annual meeting of the Society of Veterinary Epidemiology and Preventive Medicine, London, p. 94-106

Williamson, I. J. F. (1929). A study of bacterial infection in fish and certain lower vertebrates. Fishery Board of Scotland, Salmon Fisheries 11: 3

Willumsen, B. (1990). Aeromonas salmonicida subsp. salmonicida isolated from Atlantic cod and coalfish. Bull. Eur. Ass. Fish. Pathol. 3: 62-63

Manuscript first received: December 2, 1992

Revised version accepted: July 16, 1993 